\title{
Patterns in Family Policy Preferences IN THE EUROPEAN UNION
}

\author{
APRIL BRAYFIELD \\ TulaneUniversity \\ MARINA A. AdLER \\ University of Maryland, Baltimore County
}

\author{
YE LuO \\ Unizersity ofChicago
}

Thisstuctyempirically examines the relationship between national context and individual preferences fornational policy priorities related to improving family life within the European Union. Using datafrom the Eurobarometersurrey, logistic regression models indicate that publicopinion about ninepotential priorities(housing economic prospects, education, flexiblework bours, childcare, tax advantages, child allowances, parental leave, and contraception) parallels an ideological subscription to traditional gender roles, the level of economic prosperity, and the degree and type of statesupport for families with cbildren. Wealso find that weomen aremoreconcerned about policies that en hancethereconciliation of work and family, while men are more concerned about policies that support their traditionalbreadwinnerduties.

Demographic trends in family formation and family structure appear to be converging across Western Europe in the last few decades. There are fewer marriages, more lone mothers, rising divorce rates, declining and delayed fertility, and increases in women's employment. These

"Earlier versions of this paper were presented at the 1998 Annual Meetings of the American Sociological Association in San Francisco and the 1999 European Sociological Conference in Amsterdam. We thank Sandra L. Hofferth, participants at the Political \& Economic Sociology Workshop at Indiana University, the Sociology Faculty Research Group at Tulane University, and anonymous reviewers for their comments and suggestions at various stages in the project. Direct correspondence to April Brayfield, Department of Sociology, 220 Newcomb Hall, Tulane University, New Orleans, LA 70118 USA. Email: aprilb@tulane.edu. 
trends have generated political and academic debates about pronatalism, government support for particular family forms, and the most "appropriate" mechanisms for the reconciliation of work and family responsibilities. Some people may argue that similar demographic situations require similar policy responses, leading to a standardization of benefits and programs across Europe. National strategies, however, are rooted in different economic circumstances (e.g., budget concerns and relative prosperity), political processes (e.g., the role of parties and government), and cultural traditions (e.g., gender ideology), and consequently, family policies reflect the different ways that governments and populations conceptualize the family and its relationship to the state (see Hantrais and Letablier 1996).

Many prior studies have analyzed various European family policies and their associated consequences (e.g., Castles 1993; Hantrais and Letablier 1996; Kamerman 1991; Lewis 1993; Millar and Warman 1996). Scholars have also scrutinized national debates on family issues within political arenas (e.g., Macura, Eggers, and Frejka 1995). There is also an expanding literature on popular attitudes toward the welfare state, welfare services provided by the state, and the extent of state responsibility for public well-being (see Bonoli, George, and Taylor-Gooby 2000). Public opinion research helps us understand the degree to which state ideology and policy is internalized and accepted by the citizenry (Treas and Widmer 2000). Few researchers, however, have examined public opinion on the content of family policies. Yet like other scholars (Bonoli, George, and Taylor-Gooby 2000; Macura, Eggers, and Frejka 1995; Moors and Palomba 1995), we contend that popular sentiment constitutes an important link between individuals and policy outcomes, because politicians and other policymakers depend on the support of, and must respond to, their constituencies as they attempt to create and implement specific family policy choices. Thus, we explore the fit between national contexts and public opinion about the policies that should be the focus of government action.
The primary aim of this paper, then, is to identify the degree to which individual attitudes about family policy priorities vary across the national populations of the European Union (EU). Because European welfare regimes historically differ in their treatment of women as workers and/or mothers (see Misra 1998; Ostner and Lewis 1995), we also examine whether gender differences in policy preferences exist within each country. To investigate public sentiment about family policy priorities, we use data from the 1993 Eurobarometer survey (Reif and Melich 1993), which contained a topical module on family life. We limit our analysis to the twelve countries that were members of the European Union at the time of the survey: Belgium, Denmark, France, Germany, Greece, Ireland, Italy, Luxembourg, the Netherlands, Portugal, Spain, and the United Kingdom.

\section{Demographic Contexts}

Although most Western European countries experienced similar demographic trends in recent decades, they occurred at a different pace and/or magnitude. First, Europeans are having fewer children today than they did 20 years ago. In fact, with the exception of Ireland, total fertility rates are below replacement (Table 1). The combined total fertility rate for the European Union fell from 2.61 children per woman in 1960 to 1.44 children per woman in 1993 (Eurostat 1995). This downward trend in fertility has been most dramatic in countries with historically higher fertility rates, such as Spain, Italy, Portugal, Greece, and Ireland.

Second, marriage rates are also declining throughout Europe: while the number of marriages has dropped, divorce rates and the average age at first marriage have risen substantially (Eurostat 1995). Nevertheless, while Europeans are still forming families, they are not necessarily "traditional" ones, that is, legally married couples with child(ren): six out of ten Europeans live as part of a couple (married or not), and $20 \%$ of births occur outside of marriage (European Commission 1994; Eurostat 1995). These family structures vary significantly across the European Union, with a notable North-South 


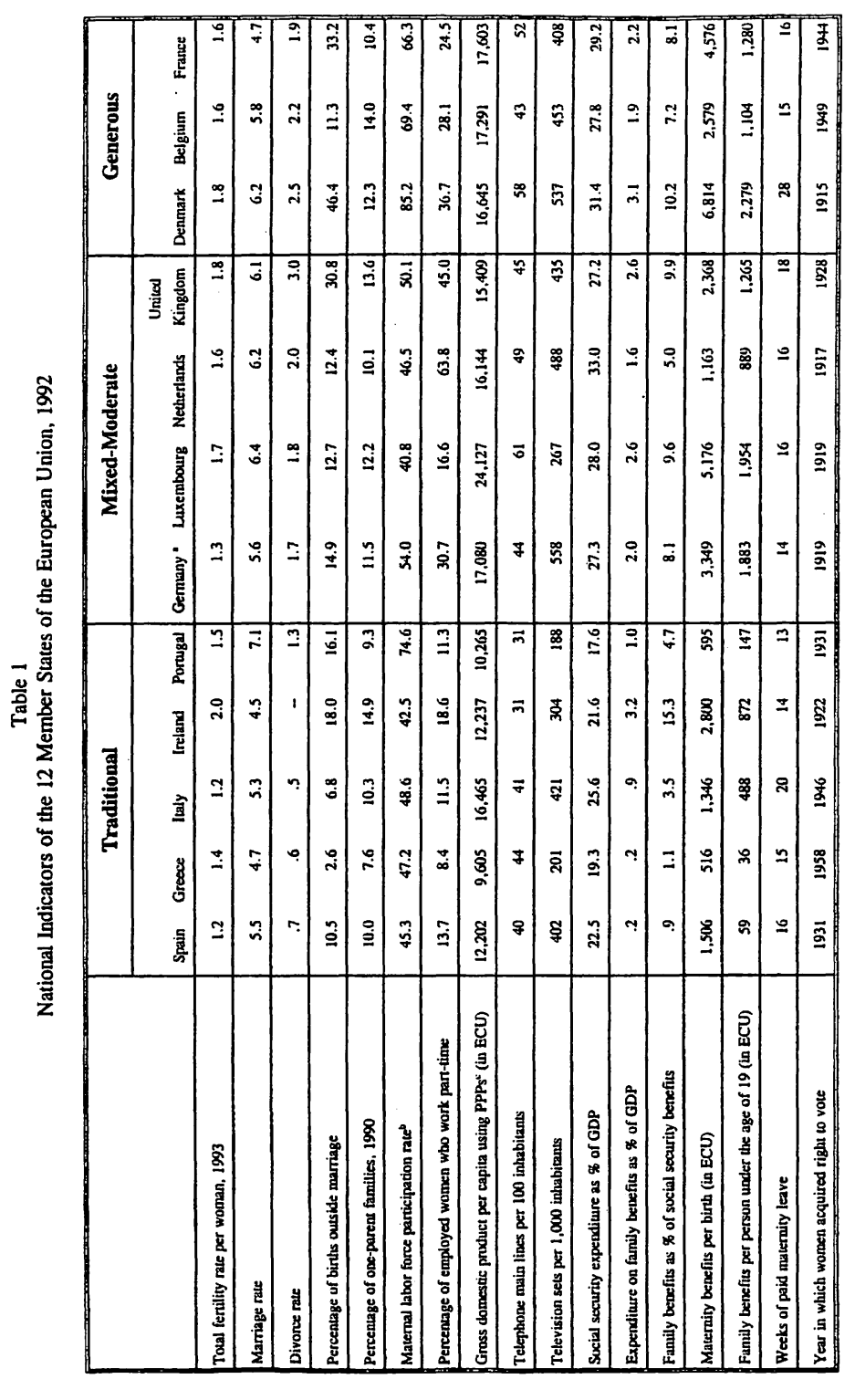

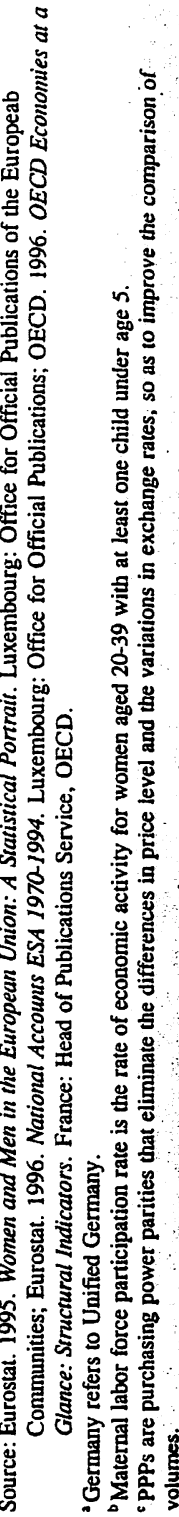

divide (see Table 1): single-parent families and cohabiting couples with children (outside of marriage) are much more common in Northern than in Southern Europe (European Commission 1994; Eurostat 1995).

Third, the general rise in women's employment has irrevocably altered the fabric of family life. Many women are delaying, or even foregoing, childbearing because of its potential negative effects on earnings, seniority, and career trajectories (see Adler 1997). This is one reason (among others) for the declining birth rates. At the same time, with increasing numbers of mothers employed outside the home, the demand for substitute child care and other domestic services has increased exponentially. Although all European countries have experienced these fundamental changes, the rate of women's economic activity, especially that of mothers with young children, varies considerably among member states: mothers in Denmark, Portugal, Belgium, and France have higher labor force participation rates than mothers in other European countries.

Despite these trends, Europeans greatly value family life and having children, albeit in fewer numbers now than in earlier decades (see Jones and Brayfield 1997; Brayfield, Jones and Adler 2001). In fact, $96 \%$ of Europeans consider the family to be the most important aspect of life (European Commission 1994). At the same time, the ability to form a viable family (of any size) is constrained by economic considerations, and these considerations vary across individuals, social classes, and countries.

\section{Family Policy Contexts}

European families receive different types and levels of support from their national governments because national policies and programs diverge in rationales, objectives, and comprehensiveness (European Commission 1994; Hantrais and Letablier 1996). Some countries have an explicit, integrated approach to family policy (e.g., Denmark, France, Luxembourg, and Portugal), while the policies of other coun- 
tries lack coherence (e.g., Italy, Greece, Spain, and the United Kingdom). The particular mixture and intensity of policies, in terms of entitlement, financial commitment, and mechanisms for delivery, differ quite substantially among the member states, depending on the national ideologies about the "welfare state" and its role in family affairs. Thus, the extent to which Europeans consider family welfare to be a private matter (as in the United Kingdom) or a public responsibility (as in Belgium, Denmark, and France) also varies cross-nationally. Despite these divergences, Western Europe has witnessed a growing acceptance of, and in some countries an outright demand for, state intervention on behalf of families (see Millar and Warman 1996). As a result, all EU member states have enacted policies intended to improve the well-being of families.

Family policy potentially covers a wide range of legislation, programs, and provisions. Policies, however, may not be recognized explicitly as family policies per se either by national governments or the general public. Obviously, governments can directly encourage childbearing by reducing the costs associated with raising children. Measures such as child allowances, birth grants, and maternity leave are identified explicitly as constituting family policy. National governments differ in the extent to which they fund these family benefits (Table 1). For example, the relative size of government expenditures on family benefits is much greater in Ireland and Denmark than in the Southern European countries. Other policies can promote family well-being, but less directly, through family-related tax provisions, subsidized housing, the creation of part-time jobs, and the availability of flexible work hours. Thus, Europeans have responded to work-family dilemmas in different ways, based on the particular economic, political, and cultural circumstances prevalent in their countries. For example, part-time employment for women is a more feasible option for combining work and family in the Netherlands than in Greece, with $63.8 \%$ of employed Dutch women and only $8.4 \%$ of employed Greek women working part time (Table 1). Regardless of their intentions, all of these policies will come under closer scrutiny as member states attempt to trim their social safety nets to reduce siz- able government deficits. Consequently, the issue of policy convergence or "harmonization" has become a hot topic for researchers and policymakers alike.

Researchers have used a variety of empirical indicators and conceptual dimensions to classify European countries into typologies or clusters (e.g., Esping-Andersen 1990; Gornick, Meyers, and Ross 1997; Lewis 1992; O'Connor 1993; Orloff 1993; Korpi 1989, 2000; Ostner and Lewis 1995). Feminist scholarship, in particular, documents the importance of gender ideology in studying welfare state regimes. Ostner and Lewis (1995: 185), for example, argue that:

As matters stand, assumptions about the existence of a male breadwinner and a dependent family consisting of a female and child are built into welfare provision to varying degrees in EU member states. Although the vast majority of countries recognize the male-breadwinner role, they differ significantly in the extent to which women are confined to homemaking and motherhood and are recognized also as workers.

Based on this logic, Ostner and Lewis (1995) classify several European countries according to the strength of the male-breadwinner norm as manifested in national tax and social security systems, the level of provisions for public childcare, and the nature of women's labor force participation. They contend that Britain, Germany, and Ireland are strong male-breadwinner countries because their social entitlement programs treat women almost exclusively as dependent wives. They classify France and Belgium as moderate male-breadwinner countries because social programs in these countries conceptualize women as wives, mothers, and workers simultaneously, and they characterize Denmark as a weak male-breadwinner country because Danish social policy defines women primarily as workers.

Papadopoulos (1998) argues that the countries that constitute "the periphery of the EU" (i.e., Ireland, Spain, Portugal, Greece, and Italy) are characterized by a centrality of the family as a social institution and as the key provider of welfare. According to Saunders (1991), 
the Italian concept of mothering involves the strong expectation for women to serve their children indefinitely. These countries also have strong orthodox religious traditions and very traditional patriarchal family structures. Consequently they have, to varying degrees and based on various indicators, very rudimentary family policies. Overall, Papadopoulos (1998) concludes that the peripheral countries have the least generous child support packages, and thus, public dissatisfaction with family policy in these countries is not surprising.

In a historical comparative analysis of the relationship between demographic changes and family policy in twenty-two countries, Gauthier (1996) proposes four main models of family policy: (1) pro-family/pro-natalist; (2) pro-traditional; (3) pro-egalitarian; and (4) pro-family but non-interventionist. She claims that family policy in France (and Quebec) fits a pro-family/pro-natalist model in which support for families, and childbearing in particular, is viewed as the responsibility of government. Under this model, measures that reduce obstacles to fertility, including support for maternal employment, are central to family policy. Gauthier (1996) places Germany in the category of the pro-traditional model, whereby preservation of the traditional male-breadwinner family dictates the nature of state support for families. Gauthier (1996) identifies Denmark (and Sweden) as exemplars of the pro-egalitarian model because of their unfaltering state support for gender equality, creating the conditions that foster the combination of family responsibilities and employment for both women and men. She characterizes Britain (and the United States) as subscribing to the pro-family but non-interventionist model in which a low level of government support for families is available, and then only to poor families. It is important to note that Gauthier (1996) acknowledges that Southern European countries do not fit well into any of her four models. Despite this limitation, her analysis highlights the importance of understanding the linkage between family policy and the complex constellation of socioeconomic and demographic circumstances as well as the historical, political, and cultural traditions of national populations.
More recently, Korpi (2000) also promotes the importance of gender and family policies in his typology of welfare states. He first develops three ideal typical models based on general family support, dual-earner support, and market-oriented gender policies. He places countries into one of these three models by using several empirical indicators, and then he refines the classification scheme by combining these gendered institutional models with four models of social insurance (i.e., basic security, targeted, encompassing, and state corporatist models). With respect to the countries in our study, Korpi's integrated scheme shows that the UK is a basic security/market oriented country with high class inequality and medium gender inequality, Denmark belongs to the basic security/dual earner group with medium class inequality and low gender inequality, Ireland and the Netherlands are in the basic security/general family support category, and Belgium, Germany, Italy, and France are in the state corporatist/ general family support category.

\section{Does Public Opinion Reflect National Context?}

Macroscopic typologies alone tell us little about how European citizens themselves view the importance of family-related policies or to what extent they agree on government priorities for intervention. Undoubtedly, public opinion should reflect differences in national context. We contend that national governments influence public opinion via public discourse about family policies in terms of how these issues are framed in the first place. For example, government officials as well as the media play important roles in persuading people to support some programs or policies, but not others. In other words, state propaganda about family issues may be internalized by individuals, and then manifested in public opinion. At the same time, the institutional character of different welfare state regimes and the varying economic situations of families in different national contexts are likely to affect public support for various family policies across countries. Moreover, some countries share a common language, religious legacies, economic situations, and family policy orientations across their national borders, and thus, we would expect public opinion to cluster 
into "attitude regimes" in a pattern similar to policy regimes or other types of structural regimes. Therefore, we hypothesize that the crossnational pattern of public opinion about government priorities for family policy should approximate the clustering of countries with somewhat similar demographic, economic, and policy contexts.

The twelve countries in our analysis appear to fall into three clusters, based on the literature about social welfare provisions in conjunction with the indicators in Table 1. The first cluster - Spain, Greece, Italy, Ireland, and Portugal - is characterized by less economic prosperity (as evidenced by lower GDP per capita and other measures of economic development), lower divorce rates, lower births outside of marriage, lower proportion of women in the labor force (except Portugal), lower expenditures for family benefits, and later year of women's enfranchisement. These countries also subscribe to a wellentrenched patriarchal family ideology and hierarchical religious traditions (Catholicism and Greek Orthodoxy). Based on low economic development, traditional gender and family patterns, and religious orthodoxy, we refer to this group of countries as the tradi. tional cluster. Another cluster-Denmark, Belgium, and France - is characterized by greater state provisions for family well-being, higher births outside of marriage (except Belgium), higher rates of maternal employment, and according to Ostner and Lewis (1995) a moderate-to-weak tradition of the male-breadwinner norm in their social policies. We refer to this group of countries as the generous cluster. The other countries - Germany, Luxembourg, the Netherlands, and the United Kingdom - fall in between the other two empirical clusters, and although Ostner and Lewis (1995) claim that the articulation of the male-breadwinner norm is strong in Germany and the United Kingdom, it is certainly not as strong in these four countries as it is in the traditional cluster. We call this grouping of countries the mixed-moderatecluster.

In short, we hypothesize that national populations who share similar structural and ideological contexts will voice similar preferences for potential targets of government action to improve family life. Resi- dents of countries with generous family policies should be more similar to each other in their policy preferences than they are to residents of countries in the traditional cluster with lower levels of economic prosperity and less integrated family policies or to residents of countries in the mixed-moderate cluster with a mixture of ideological standpoints and policy orientations. Likewise, the attitudes of residents in Spain, Greece, Italy, Ireland, and Portugal should cluster together on issues that they identify as most in need of government intervention on behalf of family well-being, especially policies designed to improve the basic standard of living. While Germany, Luxembourg, the Netherlands, and the United Kingdom clearly do not fit into the other two clusters, the structural and ideological contexts of these countries are more disparate than in the traditional or generous clusters. Hence, we would not be surprised if the policy preferences of the residents of these four countries do not neatly cluster into a similar "attitude regime."

We also examine whether gender plays a significant role in determining individual attitudes toward family policy priorities; namely we ask the question, do the policy concerns of women differ from those of men? Gender can affect the relationship between national characteristics and individual policy preferences in a number of ways. Many family policies, although gender-neutral in language (e.g., the availability of affordable, quality child care services), implicitly concern the promotion of equal opportunity for women and men, purposively helping women to more successfully balance employment and parenting roles. In general, we hypothesize that if women are the direct beneficiaries of particular family policies, they will voice stronger support for these policy priorities. In contrast, men may be less concerned about policies promoting women's employment and more concerned about policies that enhance the overall economic position of families more generally, such as policies compatible with the traditional male-breadwinner/female-homemaker model. In countries where benefits are tied to labor force participation and where a large proportion of women are in the labor force, women may be more concerned about family leave benefits and child care. In countries 
where the patriarchal family rather than the state is viewed as the key welfare provider, the lack of comprehensive family policy may be regarded as an important issue in "modernization." Moreover, the absence of family policy, by default, reinforces the role of women as caregivers of children and legitimizes their dependency on men.

Methodology

\section{Data Source}

We use data from the $39^{\text {th }}$ wave of the Eurobarometer survey (Reif and Melich 1993). In addition to standard core questions, each wave targets selected issues of concern to the Commission of the European Communities. The focus of this particular survey was public awareness of and attitudes toward the activities, institutions, and policies of the European Union as well as a special set of questions about family values. INRA (EUROPE), a European Network of Market and Public Opinion Research agencies, conducted the surveys between March 16 and April 16, 1993. The sample represents the population of the respective nationalities, aged 15 years and over, residing in each of the twelve EU member states. Finland and Norway also participated in this survey, but unfortunately Finnish respondents were not asked any of the questions concerning family life. Also, since Norway has withdrawn its application to the European Union and because our analytic objective is to examine attitudes within the European Union, we exclude Norwegian respondents. In each country, the basic sample design relied on a multi-stage, random technique, with probability of sample selection being proportional to population size and density. Throughout our analyses, we separate East and West German respondents because previous research demonstrates that regional gaps in German attitudes toward several work-family issues reflect pre-unification differences in state ideology, policies, and work-family demographics (Adler \& Brayfield 1996; Adler \& Brayfield 1997).

\section{Measurement of Family Policy Preferences}

The Eurobarometer survey asked respondents "If the purpose is to improve life for families, which three of the following things should the (national) Government make top priority for action?"

1. Availability of suitable housing

2. Improving economic prospects

3. Cost of educating children

4. Flexible working hours

5. Availability of child care arrangements

6. Tax advantages for families with children

7. Level of child allowance

8. Length of post-natal parental leave

9. Availability of contraception

These policy issues represent two basic thematic concerns: (1) a family's economic well-being, and (2) maternal employment. Items $1,2,3,6$, and 7 focus on various dimensions of the standard of living, and Items 4, 5, 8, and 9 focus mainly on women's concerns. Theoretically, each respondent should have selected three policy priorities. However, some respondents selected fewer than three items $(22.9 \%, n=3,003)$ or more than three items $(.2 \%, n=32)$. Nevertheless, the vast majority of respondents chose exactly three items other than "don't know" $(76.8 \%, n=10,074)$. One limitation of these dependent variables is that they mainly tap respondents' assessment of what should be made a top priority, implying that it may not be a priority yet. That means that respondents who are satisfied with the current prioritization of a policy may not list it as one that should be made a priority even if they believe it is very important.

\section{Analytic Strategy}

First, we calculated the percentage of respondents in each country who selected each particular policy priority, irrespective of how many issues each respondent mentioned. We used Scheffe's multiple comparison tests to detect significant differences in the national percentages for each policy issue. 
Next, we investigated whether the observed patterns in national attitudes are merely the result of compositional differences in the national samples. To do this, we estimated a logistic regression equation for each item by regressing country of residence on whether or not respondents mentioned a particular item, controlling for individual demographics (age, gender), employment-related characteristics (employment status, income quartiles), family status (presence of children, marital/partner status), and individual attitudes (attitude toward maternal employment, and attitude toward European unification). People who differ in their life circumstances may also differ in their views about policy priorities. For example, parents may have a heightened awareness of child care issues because of the immediacy of their daily lives with their children. Likewise, an individual's ideas about women's and men's family responsibilities (i.e., their gender-role ideology) and their feelings about the social and economic integration of Europe also may be relevant to his or her policy preferences.

We entered each country into the equation as a separate dummy variable, with the exception of the Netherlands, which serves as the reference country. We chose the Netherlands as the omitted reference country because it generally falls in the middle of our hypothesized clusters of countries. In this paper, we report the main net effects of national residence on public opinion; we do not provide details on the net effects of each control variable (coefficients for the control variables are available from the authors). This strategy allows us to concentrate on national differences, net of compositional variation among respondents of different countries.

To get a more comprehensive picture of the constellation of national sentiments toward desirable policy targets, we compared the most popular combinations of policy priorities within each country for respondents who chose exactly three items other than "don't know." In this paper, we present the most popular combinations out of the 84 possible combinations.
Lastly, we examined gender differences in policy preferences. We alculated the net effect of being female $(1=$ female, $0=$ male $)$ on the log odds of mentioning a particular policy item for each country, controlling for other characteristics of the respondent, i.e., age, employment status, family income, presence of children by age group, ployent status, attitude toward maternal employment, and attitude maritard European unification. We estimated these equations for each toward Eus using each policy target as a separate dependent variable, resulting in a total of 130 equations. In this paper, we present only he logistic regression coefficients for the net gender gap in policy the logistic res to focus attention on the role of gender in shaping public opinion about family policies.

\section{Results}

Table 2 presents the national percentages of respondents who selected each particular policy issue, irrespective of how many issues each respondent mentioned. There is wide variation in public opinion across EU member states, and many of the national differences are statistically significant (details of the Scheffe's tests are not shown in Table 2). To help readers identify the general clustering of countries for each policy priority, Table 3 provides a summary of the countries that form a statistically significant cluster in mentioning a particular policy priority most often (i.e., the top cluster, which varies from only one country to as many as five countries, depending on the results of the Scheffe's tests).

In general, the residents of the traditional cluster and the mixedmoderate cluster were more likely than residents of the generous cluster to choose policy priorities that concerned a family's economic well-being. First, respondents mentioned availability of suitable housing most often in Spain, the United Kingdom, and East \& West Germany (over 59\%), while it was mentioned least often in Belgium (22\%). Second, East Germans (68\%) and the French (57\%) are most likely to mention improving economic prospects. For this policy priority, there are no significant differences among the 


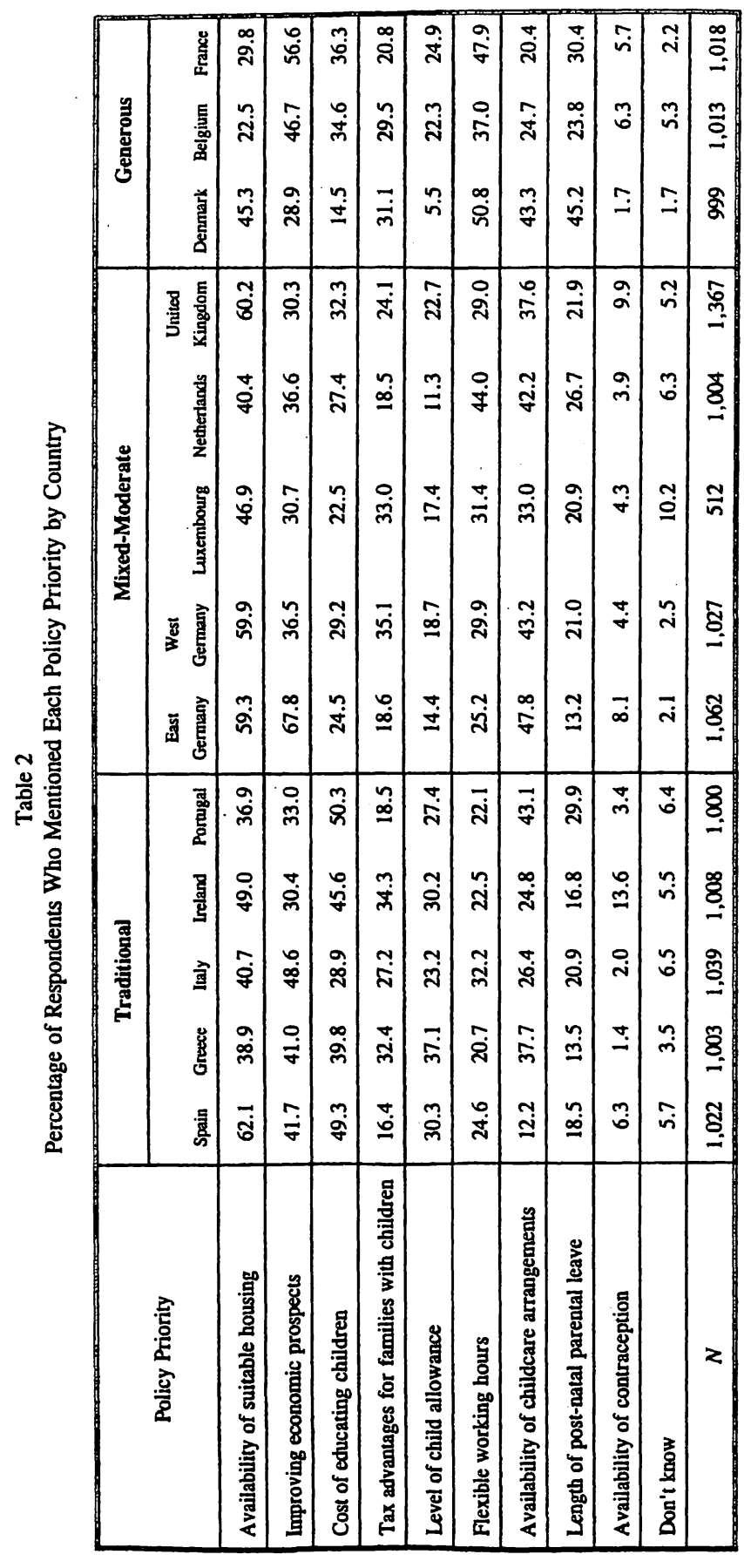

Table 3

Countries in which Each Policy Priority Is Mentioned Most Often

\begin{tabular}{|l|l|}
\hline Policy Priority & Top Cluster \\
\hline Housing & $\begin{array}{l}\text { Spain } \\
\text { United Kingdom } \\
\text { East Germany } \\
\text { West Germany }\end{array}$ \\
\hline Economic Prospects & $\begin{array}{l}\text { East Germany } \\
\text { France }\end{array}$ \\
\hline Educational Cost & $\begin{array}{l}\text { Portugal } \\
\text { Spain } \\
\text { Ireland }\end{array}$ \\
\hline Tax Advantages & $\begin{array}{l}\text { West Germany } \\
\text { Ireland } \\
\text { Luxembourg } \\
\text { Greece } \\
\text { Denmark }\end{array}$ \\
\hline Child Allowance & $\begin{array}{l}\text { Greece } \\
\text { Spain } \\
\text { Ireland }\end{array}$ \\
\hline Flexible Hours & $\begin{array}{l}\text { Denmark } \\
\text { France } \\
\text { Netherlands }\end{array}$ \\
\hline Childcare Availability & East Germany \\
\hline Parental Leave & Denmark \\
\hline Contraception & $\begin{array}{l}\text { Ireland } \\
\text { United Kingdom } \\
\text { East Germany }\end{array}$ \\
\hline
\end{tabular}

Note: We identified the top cluster of countries by conducting Scheffe's tests of significance The Scheffe procedure is the most conservative multiple-comparison test because it requires larger differences between pairs of means to achieve statistical significance. Countries that fall into the top cluster are not significantly different in the national percentages of respondents who mentioned the policy priority in question.

national percentages for Denmark, UK, Ireland, Luxembourg, Portugal, West Germany, and the Netherlands (29-36\%). Third, the cost of educating children is of greatest concern in Portugal, Spain, and Ireland (over $45 \%$ in these countries), and of least concern in Denmark and Luxembourg (15\% and 22\%, respectively). Fourth, public opinion about tax advantages for families with children appears split among three groups: Spain, Portugal, the Netherlands, East Germany, France, and United Kingdom are least concerned (16-24\%), and West Germany, Ireland, Luxem- 
bourg, Greece, and Denmark are most concerned (31-35\%), with Belgium and Italy in between. Fifth, Greek respondents (37\%) are much more likely to choose level of child allowance as a government priority, while Danish and Dutch respondents are least likely (6\% and $11 \%$, respectively), with East \& West Germans and respondents from Luxembourg also voicing lower levels of concern for this issue.

The general pattern of national sentiment about policies that promote maternal employment does not neatly coincide with our hypothesized clusters of countries. First, flexible working hours is mentioned most often in Denmark, France, and the Netherlands (over $44 \%$ ), while there are no significant differences between the eight lowest national percentages (Greece, Portugal, Ireland, Spain, East \& West Germany, United Kingdom, and Luxembourg: 20-31\%). Second, East Germans are most likely (48\%), while the Spanish (12\%) and French $(20 \%)$ are the least likely, to choose the availability of child carearrangements as a government priority. Although there appears to be a gap between Spanish and French respondents, this difference is not statistically significant. Third, length of post-natal parental leave is mentioned most often by Danish respondents (45\%) and least often by respondents in East \& West Germany, Luxembourg, Italy, Spain, Ireland, and Greece (13-21\%). Fourth, few respondents consider availability of contraception to be a priority in any country, but respondents in Ireland, United Kingdom, and East Germany voice somewhat (significantly) higher levels of concern than respondents in the other countries.

Are these observed patterns simply the result of compositional differences in the national samples? The results in Table 4 demonstrate that national differences in perceptions of policy priorities to improve family life are not solely attributable to variations in the demographic configurations of member states. Although compositional differences do reduce the size and statistical significance of some national gaps, the basic cross-national patterns of policy priorities are similar to the unadjusted percentages.

\section{Paternsin Family Po}

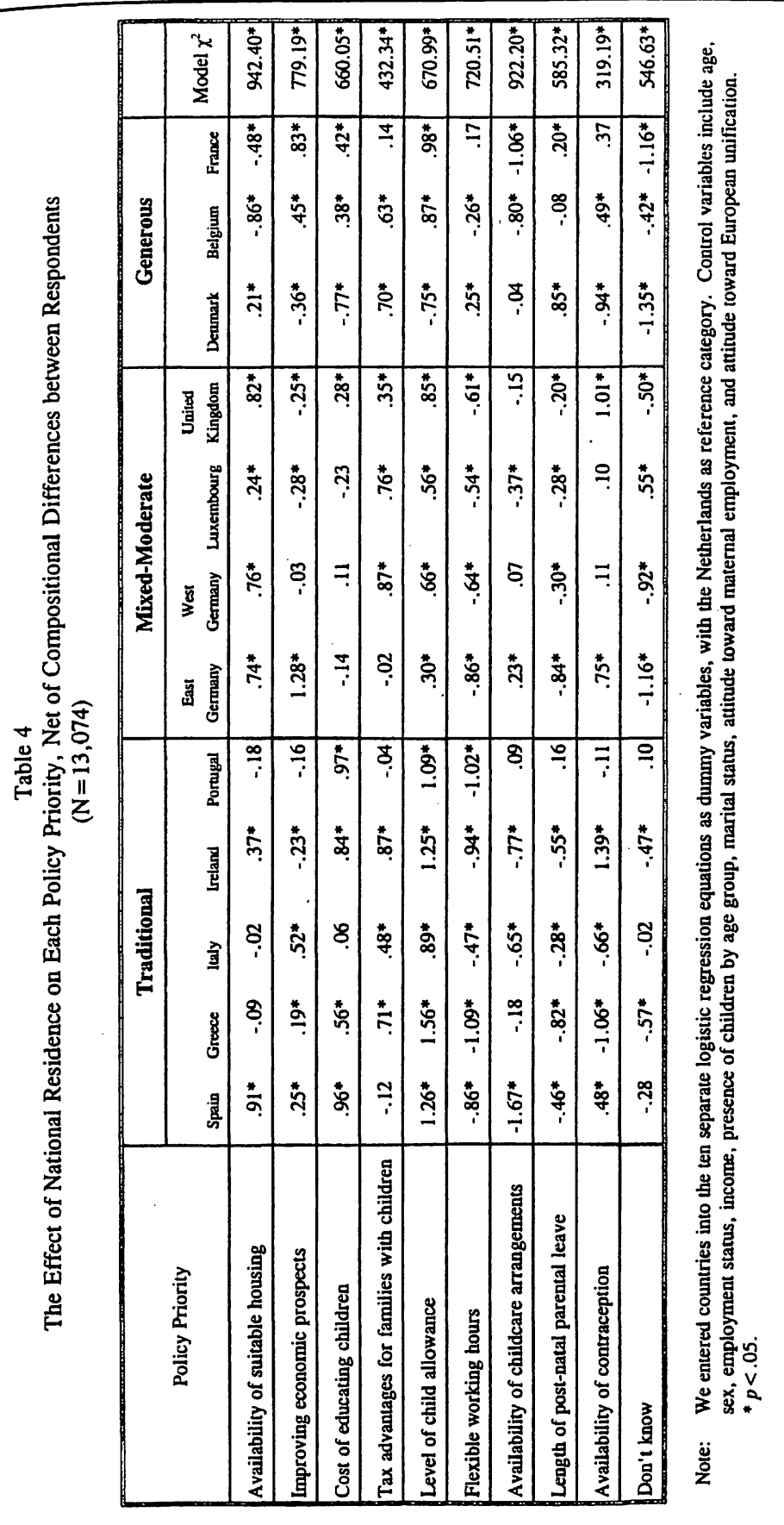


Recall that we hypothesized that countries would cluster into three groups based on the various constellations of available support sys tems and national demographic trends. For example, we expected that while people from Germany, Luxembourg, and the United Kingdom would voice policy preferences similar to those of people from the Netherlands (the mixed-moderate cluster), people from Belgium, Denmark, and France (the generous cluster) would be less concerned about a particular policy than Dutch people (the excluded reference group in the logistic regression equations). We also expected people from Spain, Greece, Italy, Ireland, and Portugal (the traditional cluster) to be more concerned about that same policy than Dutch people.

The observed cross-national pattern, however, is not so clear; there is much variation in the clustering of countries across the diverse policy priorities. Compared to the Netherlands, housing is a higher priority issue in Spain, the United Kingdom, and both East and West Germany and to a lesser extent in Ireland, Denmark, and Luxembourg. Yet it is of significantly less importance to Belgians and the French. Economic prospects are of much greater concern in East Germany and France than elsewhere, relative to the Netherlands. Educational costs stand out in Portugal, Spain, and Ireland while Danes are much less concerned than the Dutch. Respondents from Ireland, West Germany, Luxembourg, and Denmark are more in favor of making tax advantages a priority than respondents in the Netherlands. Spanish, Irish, and Portuguese respondents are much more worried about child allowances, while Danish respondents are less worried than those in the Netherlands. While respondents from most of the countries are less worried about flexible working hours than the Dutch, for Danish respondents flexible working hours are a higher priority. Compared to the Dutch, East Germans voice more interest in child care policy, while Spaniards and the French voice less interest. Whereas East Germans and Greeks are less concerned about parental leave, Danes are more concerned. Compared to the Dutch, UK and Irish respondents are more likely to consider contraception a priority, and Greeks and Danes are less concerned about this issue.

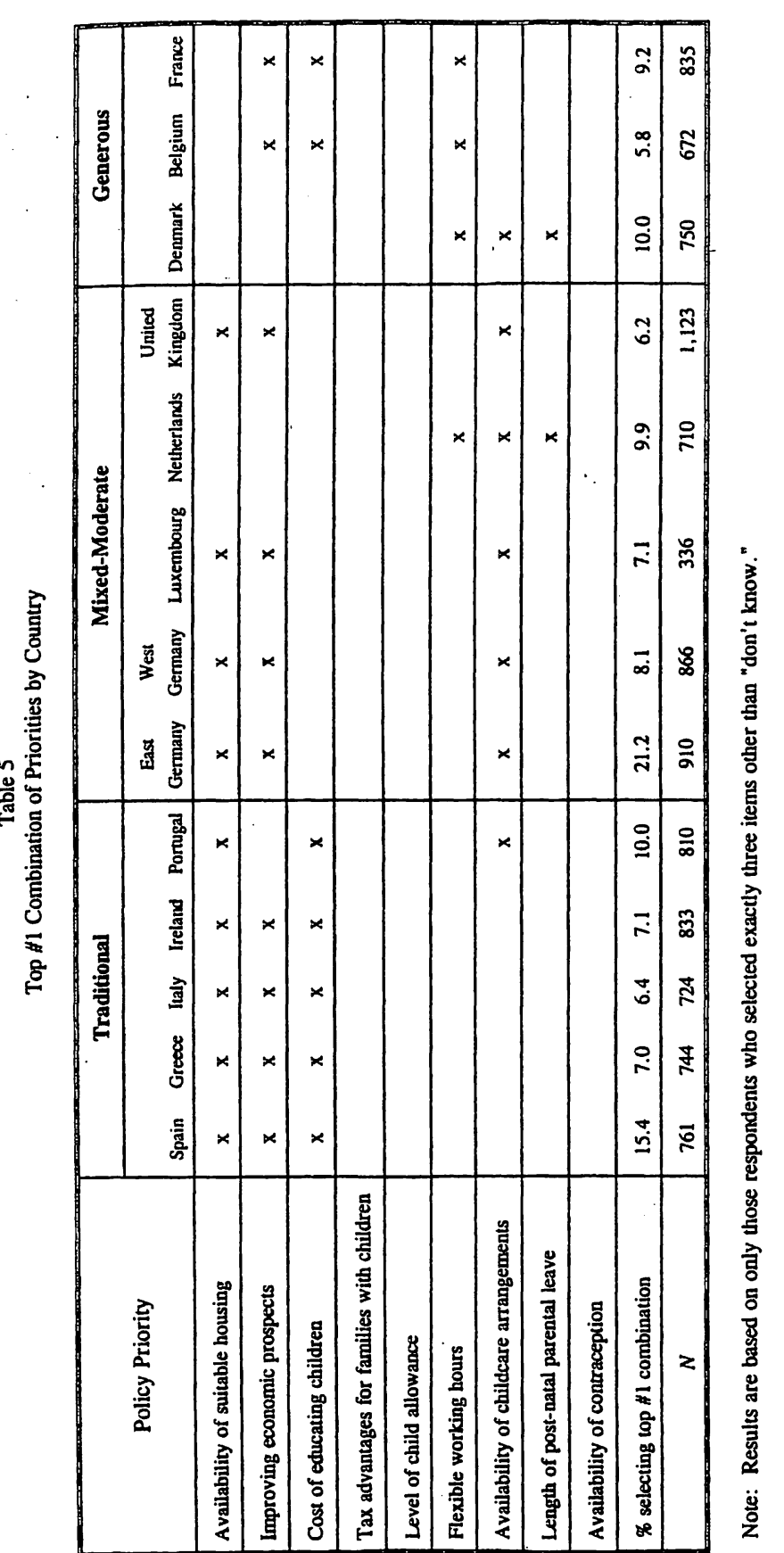




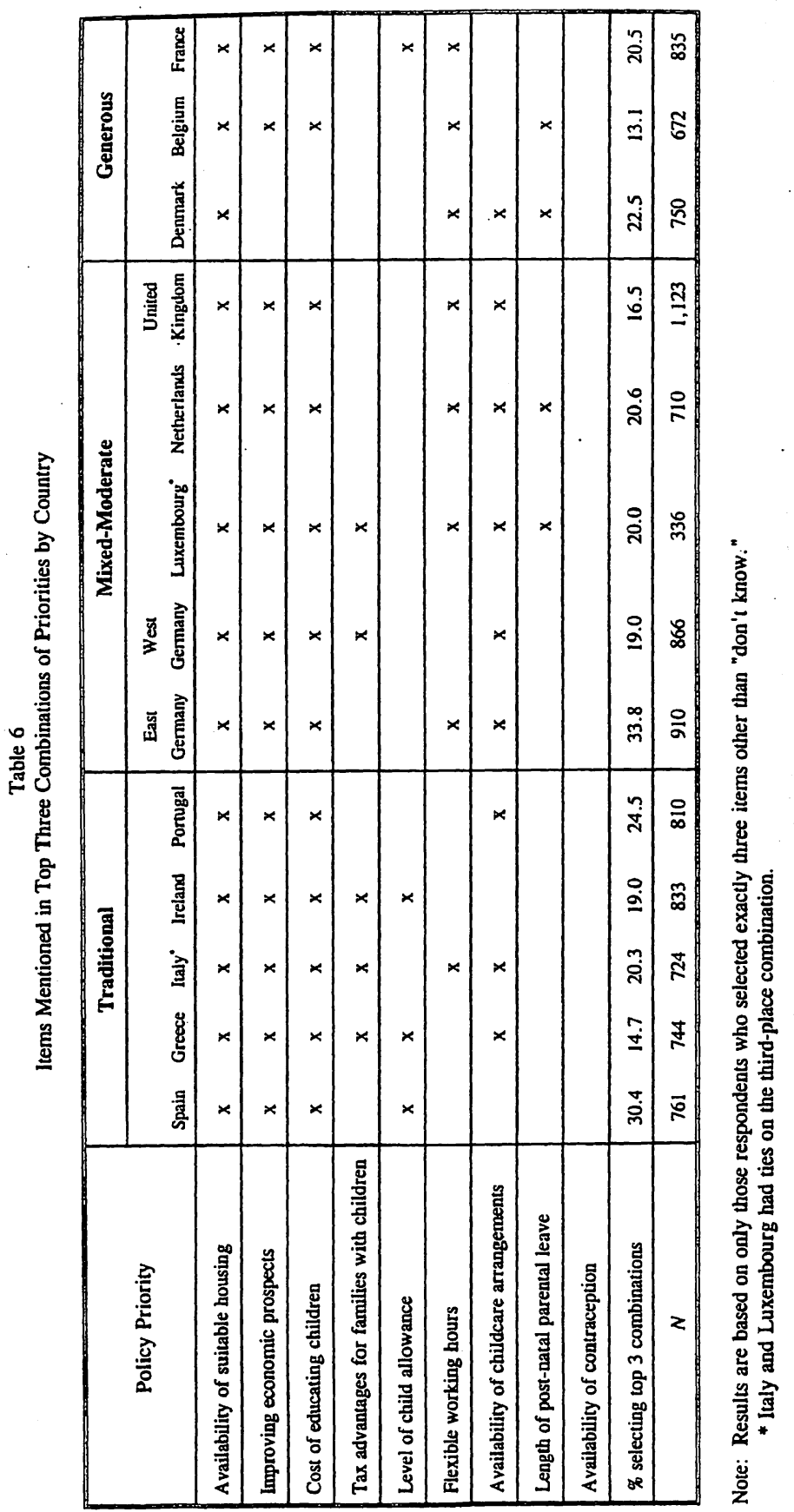

Next, we compare the most popular combinations of policy targets within each country for respondents who chose exactly three items other than “don't know." Table 5 presents the top combination within each country. Because the most popular combinations represent such low percentages of the national samples, we also present the top three combinations in Table 6 to get a more comprehensive picture of the national sentiments toward desirable targets.

Taken together, these tables show some support for our hypothesized clusters, but it would be more appropriate to divide the countries into four, not three, empirical clusters. Respondents from the traditional countries - Spain, Greece, Italy, Ireland, and Portugal - are most similar in their concerns about housing, economic prospects, and educational costs. Respondents from Belgium and France, two of the three countries in our hypothesized generous cluster, are similar in choosing economic prospects, educational costs, and flexible working hours. But surprisingly, respondents from Denmark (hypothesized generous cluster) and the Netherlands (hypothesized mixed-moderate cluster) - two countries that are quite different in a number of ways - choose flexible working hours, child care, and parental leave. Although the Dutch are most supportive and Danes are least supportive of the supranational involvement of the European Union in domestic family policy $(54 \%$ versus $19 \%$ ), they choose the same combination of policy priorities. The remaining respondents from the UK, Luxembourg, and Germany (three of the four countries from our hypothesized mixed-moderate cluster) choose housing, economic prospects, and child care as top priorities.

These empirical clusters make sense given the different national contexts. People in countries with lower levels of economic prosperity, for example, are most concerned about basic survival measures, like improving their economic prospects. And people in countries in which housing is problematic, and in which there is no explicit link between family policy and housing, are more likely to consider it a high priority. 
But there is another way to interpret why national populations select particular issues as a high priority. Note that educational costs are a priority in the two empirical clusters that fall on the opposite ends of the continuum. State financial assistance to parents for their children's educational costs is most generous in France and Belgium, and at the same time, it is least generous in the Southern European countries and Ireland. Yet respondents in both clusters prioritize educational costs. This outcome suggests that people favor particular policy priorities for two reasons. First, people may voice a concern about a particular policy area because that benefit, program, or policy is seriously lacking in some way, falls short of their expectations, or may be cut in the near future. Second, people may select a particular policy priority because it is already a vital component of their national policy, but they desire further expansion of its benefits.

Our secondary research question focuses on gender differences in public opinion. Table 7 presents the net effect of gender on the log odds of mentioning a particular policy item for each country, controlling for other characteristics of the respondent.

We highlight three general points about these results. First, we find that gender influences attitudes toward a greater number of policy targets in the Netherlands than elsewhere. This finding reinforces the Netherlands' "special status" in terms of various other apparently contradictory dimensions, such as low female labor force participation, relatively high social provisions, and a strong Catholic tradition. Second, gender has no effect at all on Greek, Italian, or Portuguese attitudes toward any policy target. Note that all three of these countries fall into the traditional cluster. Future research needs to uncover the reasons why gender helps predict public opinion on family policy in some countries but not in others. The answer may have something to do with the severity of economic disadvantage in that the interests of women and men may be more likely to converge in less prosperous countries because of their focus on basic survival. 
Third, we find some, albeit limited, support for our contention that women place a higher priority on policies that promote women's employment and the reconciliation of work and fam ily demands, while men prioritize policies that coincide more with their traditional breadwinner responsibilities. Women are more likely than men to mention flexible working hours as priority in many countries (Denmark, West Germany, Spain France, the Netherlands, and the United Kingdom). Women are also more likely than men to mention childcare (in Belgium, the Netherlands, and the United Kingdom) and parental leave (in Spain, France, and the Netherlands). Flexible hours, childcare, and parental leave are three obvious ways to support maternal employment. Men, however, are more likely than women to mention housing (in Denmark and the Netherlands), economic prospects (in the United Kingdom), tax relief (in East Germany and the Netherlands) - all issues directly related to the financial position of the family and the traditional responsibility of men as breadwinners and providers.

The effects of gender on attitudes toward educational costs of children are perplexing. Women are less likely than men to mention educational costs in Denmark and Ireland, but women are more likely than men to mention this issue in the Netherlands. Future research should investigate the nature of these gender gaps: Why do women and men differ in their demands to target educational costs as a policy priority?

\section{Condusion}

Our analysis confirms that the national patterns of public opinion about family policy priorities roughly parallel the countries' subscription to traditional gender ideology, level of economic prosperity, and the degree and type of state support for families with children. Not only do national indicators reflect that Belgium, Denmark, and France are characterized by relatively weak male-breadwinner norms, their residents voice strong concern for protecting their extensive state support for families. The countries with the lowest levels of economic prosperity - Southern Europe and Ireland - are also the ones with well-entrenched gender ideologies and the least coherent family policies, and thus, it is reasonable that the residents of these countries are most concerned about basic survival measures, like the availability of suitable housing and improving their economic prospects. The countries between these two groups exhibit greater variety in policy preferences because of dissimilarities in their historical, cultural, and economic circumstances.

Skocpol and Amenta (1986) argue convincingly that the development of social policies is historically contingent upon various agents, such as the Catholic Church, labor unions, the women's movement, and left-wing parties (see also Misra 1998). For example, the Catholic Church has supported family policy in France, Ireland, Italy, and Denmark. The women's movement has fostered the expansion of maternal leave and child care policies in France, Denmark, and the United Kingdom. And labor unions have helped Italian women. These organizations have been instrumental in developing policies that purposively attempt to reduce gender inequalities in Scandinavia or in maintaining the male-breadwinner norm in Germany. Popular sentiments could potentially become another such agent of social change if mobilized in support of specific family policies. Our research suggests the presence of "attitude regimes" that link national characteristics and individual attitudes in particular patterns.

Our analysis also reveals a gender gap in family policy preferences. In general, women are more likely to be concerned about workfamily reconciliation, whereas men's views align more with the traditional male-breadwinner style of family support. This divergence in public opinion confronts European policymakers who advocate gender-sensitive policies that support all family forms, not just traditional ones. Clearly, some families, especially poor families and lone mothers, need both financial support and measures that ease the combination of employment and parenthood. Given the convergence of economic demands on families, both mothers 
and fathers are spending more time in employment, leaving little time to spend with their children and each other. Parental leave for women as well as for men may be just as important as finan. cial assistance in supporting future generations of diverse families.

Our research contributes to the literature on comparative family policy from the angle of public opinion. The mixed results regarding the convergence or divergence of public views about family policy priorities in Europe underline the significance of taking national context into account. We agree with Hantrais and Letablier's (1996: 189) assertion that:

comparative analysis is likely to make a greater contribution to the understanding of national systems if it concentrates on try ing to unravel the cultural embeddedness of different family forms and of the institutions involved in the policymaking process.

Toward this objective, we suggest that public opinion constitutes an important dimension of the national environments in which family policies originate, and thus, we invite researchers to pay more attention to the cultural and economic embeddedness of public opinion and its relationship to policy change. Clearly, a next step in gleaning deeper insights into attitude regimes would involve the in-depth analysis of various "ideal-typical" countries that represent each cluster. The goal would be to examine under what circumstances the dialectical process between policy development and public sentiments of policy priorities leads to major changes in family formation over time.

\section{References}

Adler, Marina A. 1997. "Social Change and Declines in Marriage and Fertility in Eastern Germany." Journal of Marriage and the Family 59(1):37-49.

Adler, Marina A. and April Brayfield. 1997. "Women's Work Values in Unified Germany: Regional Differences as Remnants of the Past." Work and Occupations 24(2):245-66.
Adler, Marina A. and April Brayfield. 1996. "East-West Differences in Atritudes About Employment and Family in Germany." The Sociological Quarterly 37(2):245-60.

rayfield, April, Rachel Jones, and Marina Adler. 2001. "Harmonizing Work and Family in the European Union: Public Perceptions of Children as an Obstacle to Women's Employment." Pp. 179202 in Women's Employment in a Comparative Perspective, edited by Tanja van der Lippe and Liset van Dijk. New York: Aldine de Gruyter.

Bonoli, Giuliano, Vic George, and Peter Taylor-Gooby. 2000. "Welfare Priorities: The Narrowing of the National Consciousness." Pp. 72-95 in European Welfare Futures. Maldin, MA: Blackwell.

Castles, Francis. 1993. Families of Nations: Patterns of Public Policy in Western Democracies. Dartmouth: Aldershot.

Deflem, Mathieu and Fred C. Pampel. 1996. "The Myth of Postnational Identity: Popular Support for European Unification." Social Forces 75(1):119-43.

Esping-Andersen, Gøsta. 1990. The Three Worlds of Welfare Capitalism. Princeton, NJ: Princeton University Press.

European Commission, Directorate-General for Employment, Industrial Relations and Social Affairs. 1994. "The European Union and the Family." Social Europe no. 1.

Eurostat. 1995. Women and Men in the European Union: A Statistical Portrait. Luxembourg: Office for Official Publications of the European Communities.

Gauthier, Anne Hélène. 1996. The State and the Family: A Comparative Analy sis of Family Policies in Industrialized Countries. Oxford: Clarendon Press.

Gornick, Janet, Marcia Meyers, and Katherin Ross. 1997. "Supporting the Employment of Mothers: Policy Variation Across Fourteen Welfare States." Journal of European Social Policy 7(1):45-70.

Hantrais, Linda and Marie-Thérèse Letablier. 1996. Families and Fam. ily Policy in Europe. New York: Longman.

Jones, Rachel K. and April Brayfield. 1997. "Life's Greatest Joy?: European Attitudes Toward the Centrality of Children." Social Forces 75(4):1239-70.

Kamerman, Sheila B. 1991. "Child Care Policies and Programs: An International Overview." Journal of Social Issues 47(2):179-96.

Korpi, Walter. 2000. "Faces of Inequaltiy: Gender, Class and Patterns of Inequalities in Different Types of Welfare States." Social Politics 7:127-191. 
Korpi, Walter. 1989. "Power, Politics, and State Autonomy in the Development of Social Citizenship." American Sociological Review 54:309-28.

Lewis, Jane. 1993. "Introduction: Women, Work, Family and Social Policies in Europe." Pp. 1-24 in Women and Social Policies in Europe: Work, Family and the State, edited by Jane Lewis. Aldershot: Edward Elgar.

Lewis, Jane. 1992. "Gender and the Development of Welfare Regimes.” Journal of European Social Policy 3:159-73.

Liebert, Ulrike. 2001. "Degendering Care and Engendering Freedom." Pp. 261-288 in Women E Welfare: Theory and Practice in the United States and Europe, edited by Nancy Hirschmann and Ulrike Liebert. New Brunswick: Rutgers.

Macura, Miroslav, Mitchell Eggers, and Tomas Frejka. 1995. "Demographic Change and Public Policy in Europe." Pp. 8-44 in Population, Family and Welfare: A Comparative Survey of European Attitudes, Volume 1, edited by Hein Moors and Rossella Palomba. Oxford: Clarendon Press.

Millar, Jane and A. Warman. 1996. Family Obligations in Europe. London: Family Policy Studies Centre.

Misra, Joya. 1998. "Mothers or Workers? The Value of Women's Labor: Women and the Emergence of Family Allowance Policy." Gender $\varepsilon$ Society 12(4):376-399.

Moors, Hein and Rossella Palomba. 1995. Population, Family and Welfare: $A$ Comparative Survey of European Attitudes, Volume 1. Oxford: Clarendon Press.

O'Connor, Julia. 1993. "Gender, Class and Citizenship in the Comparative Analysis of Welfare Regimes: Theoretical and Methodological Issues." British Journal of Sociology 44(3):501-18.

Orloff, Ann Shola. 1993. "Gender and the Social Rights of Citizenhip: The Comparative Analysis of Gender Relations and Welfare States." American Sociological Review 58(3):303-328.

Ostner, Ilona and Jane Lewis. 1995. "Gender and the Evolution of European Social Policies." Pp. 159-94 in European Social Policy: Between Fragmentation and Integration, edited by Stephan Liebfreid and Paul Pierson. Washington, DC: Brookings Institute.

Papadopoulos, Theodoros N. 1998. "Greek Family Policy from a Comparative Perspective." Pp.47-57 in Women, Work and the Family in Europe, edited by Eileen Drew, Ruth Emerek and Evelyn Mahon. New York: Routledge. if Karlheinz and Anna Melich. 1993. Euro-Barometer 39.0: European Community Policies and Family Life, March-April 1993 [computer file]. Conducted by INRA (Europe), Brussels. Ann Arbor, MI: Inter-university Consortium for Political and Social Research producer], 1993. Koeln, Germany: Zentralarchiv fuer empirische Sozialforschung/Ann Arbor, MI: Inter-university Consortium for Political and Social Research [distributors], 1994.

Saunders, George R. 1991. "Cultural Values, Child Care, and Parenting: The Italian Experience in Anthropological Perspective.” Pp.435 460 in Parental Leave and Child Care, edited by Janet Shibley Hyde and Marilyn J. Essex. Philadelphia: Temple University Press.

Skocpol, Theda and Edwin Amenta. 1986. "States and Social Policies." An nual Review of Sociology 12:131-57.

Treas, Judith and Eric D. Widmer. 2000. "Married Women's Employment Over the Life Course: Attitudes in Cross-national Perspective.” Social Forces 78:1409-1436. 